\title{
Synthesis and Characterization of Bioglass 45S Doped with Ag
}

\author{
Bui Xuan Vuong* \\ Sai Gon University, 273 An Duong Vuong Road, Ward 3, District 5, Ho Chi Minh City \\ Received 08 October 2017 \\ Revised 16 March 2018; Accepted 16 March 2018
}

\begin{abstract}
The bioglass 45S doped with $\mathrm{Ag}$ (45S-Ag) was successful synthesized by melting method. The influence of doping Ag on the glass matrix was highlighted by DTA method. XRD analysis confirmed the amorphous structure of synthetic glass. The presence of Ag element was controled by EDX analysis. "In vitro" of synthesized glass was effectuated by soaking of glass powder in SBF solution. EDX result indicated that silver was released when immersing derivative bioglass in SBF solution and silver is an antibacterial agent. XRD and SEM confirmed the bioactivity of glass $45 \mathrm{~S}-\mathrm{Ag}$ by the apatite formation on its surface.
\end{abstract}

Keywords: Bioglass, bioactivity, Ag, 45S-Ag, melting, SBF.

\section{Introduction}

The first bioglass was discovered by L. L. Hench. It named bioglass $45 \mathrm{~S}$ with chemical composition 45SiO2-24.5CaO-24.5Na2O6P2O5 (wt\%) and synthesized by melting method. It was used as an implant material in the human body to repair and replace diseased or damaged bone. Its bioactivity based on the ability to form a hydroxyapatite layer: $\mathrm{Ca} 6(\mathrm{PO} 4) 10(\mathrm{OH}) 2(\mathrm{HA})$ on the surface when immersing in a physiological solution or implanted in the human body. The formation of apatite layer promotes the adhesion of bone tissues and permits an intimate bone-bonding with the implants. Consequently, the bone

\footnotetext{
* Tel.: 84-1276517788.

Email: buixuanvuongsgu@ gmail.com https://doi.org/10.25073/2588-1140/vnunst.4692
}

architecture is repaired and reconstructed [1,2]. After the L. L. Hench's discovery, many derivative bioglasses have been elaborated and estimated. That has opened up potential applications of bioglass material.

In recent years, the scientists are looking towards developing new bioactive materials doped with the silver element. In these biomaterials, the silver is considered as a bioactive agent. It plays an important role to limit the bacterial activity on biomaterials, resulting in the improvement of biological properties $[3,4]$.

This work aim to synthesize the bioglass 45S doped with Ag by melting method. The percentage of $\mathrm{Ag} 2 \mathrm{O} \quad(0,1 \quad \mathrm{wt} \%)$ was incorporated into the glass (synthetic glass noted $45 \mathrm{~S}-\mathrm{Ag}$ ). Some analysis techniques such as DTA, XRD, EDX, and SEM were used to investigate the synthesized biomaterial. 


\section{Experimental methods}

Synthesis of bioglass $45 \mathrm{~S}$ doped with $\mathrm{Ag}$ (45S-Ag)

The original bioglass of $\mathrm{L}$. L. Hench is $45 \mathrm{~S}$ $(45 \mathrm{SiO} 2-24.5 \mathrm{CaO}-24.5 \mathrm{Na} 2 \mathrm{O}-6 \mathrm{P} 2 \mathrm{O} 5$ wt $\%)$. In this study, bioglass $45 \mathrm{~S}$ doped with $0.1 \mathrm{wt} \%$ of $\mathrm{Ag} 2 \mathrm{O}(45 \mathrm{~S}-\mathrm{Ag})$ was synthesized by melting of a powder mixture of $\mathrm{CaSiO} 3$, $\mathrm{Na} 2 \mathrm{SiO} 3, \mathrm{Na} 3 \mathrm{P} 3 \mathrm{O} 9$ and $\mathrm{Ag} 2 \mathrm{O}$ at 1400 oC during 3 hours. At high temperature, $\mathrm{Ag} 2 \mathrm{O}$ was diffused and $\mathrm{Ag}+$ replaced the positions of $\mathrm{Na}+$ and $\mathrm{Ca} 2+$ ions in the structure of bioglass. It is considered that one $\mathrm{Na}+$ is equivalent to one $\mathrm{Ag}+$ and one $\mathrm{Ca} 2+$ correspond to two $\mathrm{Ag}+$ ions $[4,5]$ (Fig. 1). The obtained bulk glasses were ground into powder and sieved to achieve the bio-glass particles with size less than $100 \mu \mathrm{m}$.Lire phonétiquement

Chemical reactions at high temperature are below:

$\begin{array}{lll}\mathrm{CaSiO} 3 & \rightarrow & \mathrm{CaO}+\mathrm{SiO} 2 \\ \mathrm{Na} 2 \mathrm{SiO} 3 & \rightarrow & \mathrm{Na} 2 \mathrm{O}+\mathrm{SiO} 2 \\ (\mathrm{NaPO} 3) 3 & \rightarrow & 3 / 2 \mathrm{Na} 2 \mathrm{O}+3 / 2 \mathrm{P} 2 \mathrm{O} 5\end{array}$

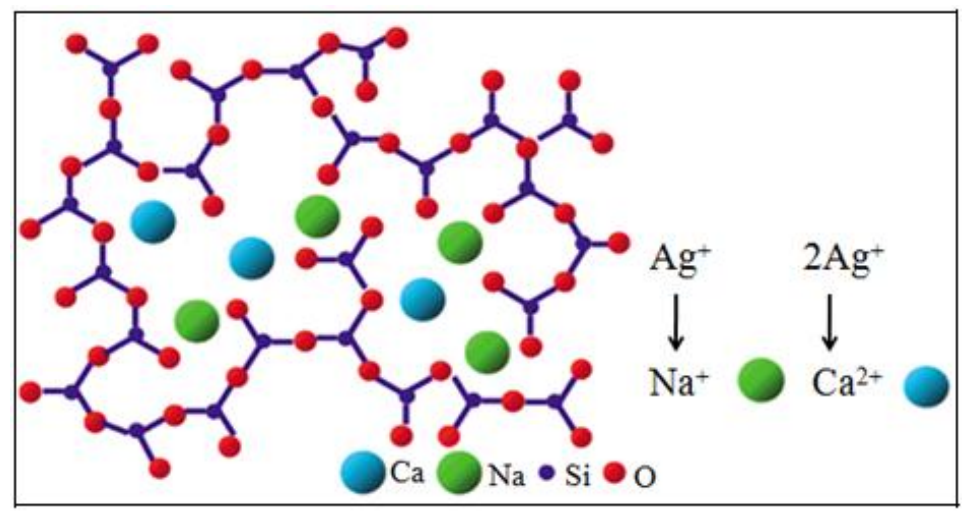

Figure 1. Elemental structure of the synthetic bioglass 45S-Ag [4, 5].

\section{In vitro experiment}

"In vitro" bioactivity of $45 \mathrm{~S}-\mathrm{Ag}$ was investigated by soaking $100 \mathrm{mg}$ of powdered samples with $200 \mathrm{ml}$ of simulated body fluid (SBF). The SBF solutionwas prepared bythe method which is reported by Kokubo et al [6]. SBF solution has similar characteristics of $\mathrm{pH}$, and chemical composition to human blood plasma. Immersion were maintained at body temperature $\left(37^{\circ} \mathrm{C}\right)$, and agitation $(50$ tours/min) during $0,3,7$ and 15 days. Then the glass powders were removed and rinsed with deionized water to stop the exchange reactions, and continuously rinsed absolute alcohol. After that the powder samples were dried and stored for further investigation of the formation of HA layer.

\section{Physico-chemical characterizations}

Differential thermal analysis (DTA) was used to provide data on the transformations that have occurred, such as glass transitions, crystallization and melting point of derivative glass. In order to characterize the amorphous character of synthetic bioglass and evaluate the formation of apatite layer after "in vitro" assays, X-ray diffraction (XRD) measurements were carried on Bruker D8 Advance diffractometer. The XRD data were acquired in the range of $10-70^{\circ}(2 \theta)$ with a scanning speed of $1 \%$ min. Scanning Electron Microscopy (SEM) (Model JSM-6301, JEOL) was used to evaluate the morphological surface of synthetic bioglass before and after immersion in the SBF 
solution. Energy dispersive X-ray (EDX) was used to analyse the elemental presence in biomaterial.

\section{Results and discussion}

\section{DTA analysis}

Figure 1 presents the DTA analyses of bioglass $45 \mathrm{~S}$ and 45S-Ag. Obtained data showed an increase of glass transition temperature when glass doped with $\mathrm{Ag}_{2} \mathrm{O}$. While, crystallization, and fusion temperatures were decreased (Table 1). The obtained result illustrated the effect of $\mathrm{Ag}$ from $\mathrm{Ag}_{2} \mathrm{O}$ on the glassy matrix of bioglass $45 \mathrm{~S}$. This also confirmed the formation of the new glass 45S$\mathrm{Ag}$ synthesized by melting method.
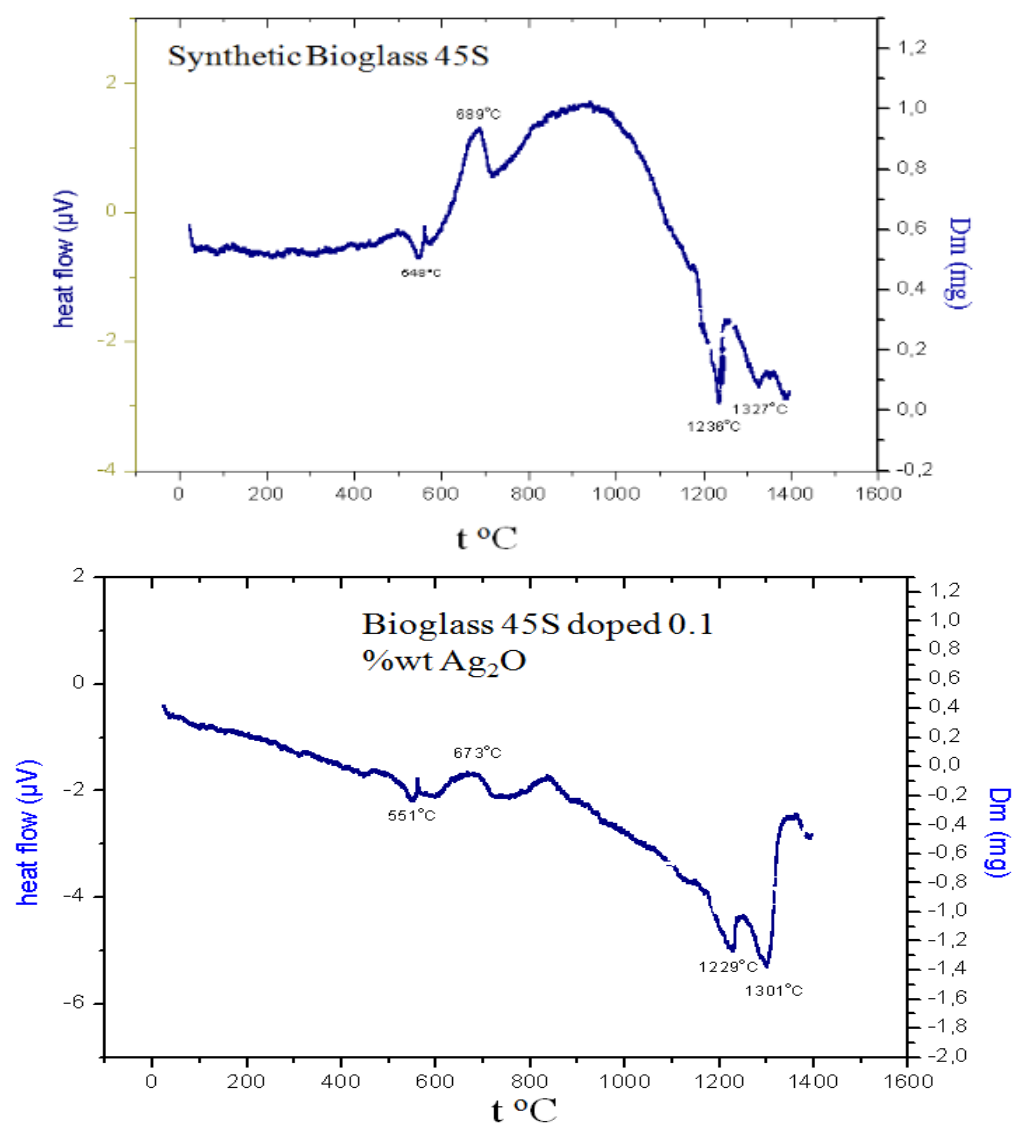

Figure 1. DTA data of bioglass $45 \mathrm{~S}$ and $45 \mathrm{~S}-\mathrm{Ag}$.

Table 1. Temperature data of $45 \mathrm{~S}$ and $45 \mathrm{~S}-\mathrm{Ag}$

\begin{tabular}{lllll}
\hline \multirow{2}{*}{ Materials } & \multicolumn{4}{c}{ Temperature data $\left({ }^{\circ} \mathrm{C}\right)$} \\
\cline { 2 - 5 } & Glass transition temperature $\mathrm{t}_{\mathrm{t}}$ & Crystallizationtemperature $\mathrm{t}_{\mathrm{c}}$ & \multicolumn{2}{l}{ Fusion temperatures } \\
$\mathrm{t}_{\mathrm{f} 1}$ and $\mathrm{t}_{\mathrm{f} 2}$ & \\
\hline $45 \mathrm{~S}$ & 548 & 689 & 1236 & 1327 \\
$45 \mathrm{~S}-\mathrm{Ag}$ & 551 & 673 & 1229 & 1301 \\
\hline
\end{tabular}


Figure 2 presents the XRD analysis of bioglass 45S-Ag before and after "In vitro" experiment. XRD diagram of standard HA is showed to evaluate the bioactivity of bioglass 45S-Ag material.

X-ray diffractogram of $45 \mathrm{~S}-\mathrm{Ag}$ showed a diffraction halo which is characteristic of the amorphous material. This is one of the important property of glasses that differ from the crystalline solid materials. The amorphous structure of glass doesn't contain planes of atoms at long distance. No peaks of $\mathrm{Ag}_{2} \mathrm{O}$ or $\mathrm{Ag}$ could be observed. This may be due to the small amount of $\mathrm{Ag}$ element incorporated into the glassy network. After 15 and 30 days of immersion in SBF solution, XRD diagrams of glass 45S-Ag presented the sharp peaks corresponding to the hydroxyapatite (HA) phase [7, 8] (Fig. 2). The formation of a new apatite layer on the glass surface illustrated the bioactivity of bioglass doped with $0.1 \mathrm{wt} \%$ of $\mathrm{Ag}_{2} \mathrm{O}$. This apatite layer is the linking between the artificial implant and the natural bone.

\section{Energy Dispersive X-Ray Analysis (EDX)}

EDX result strongly confirmed the presence of silver in derivative bioglass (Table 2 and Fiure 3). After 30 days soaking in SBF fluid, the Ag concentration was zero (Table 3 and Fiure 4). This highlighted the release of $\mathrm{Ag}$ element from derivative glass to SBF solution during immersion times. $\mathrm{The}^{\mathrm{Ag}^{+}}$ions play an important role as an antibacterial agent. So, when this derivative bioglass is inserted into human body, it can damage to bacteria.

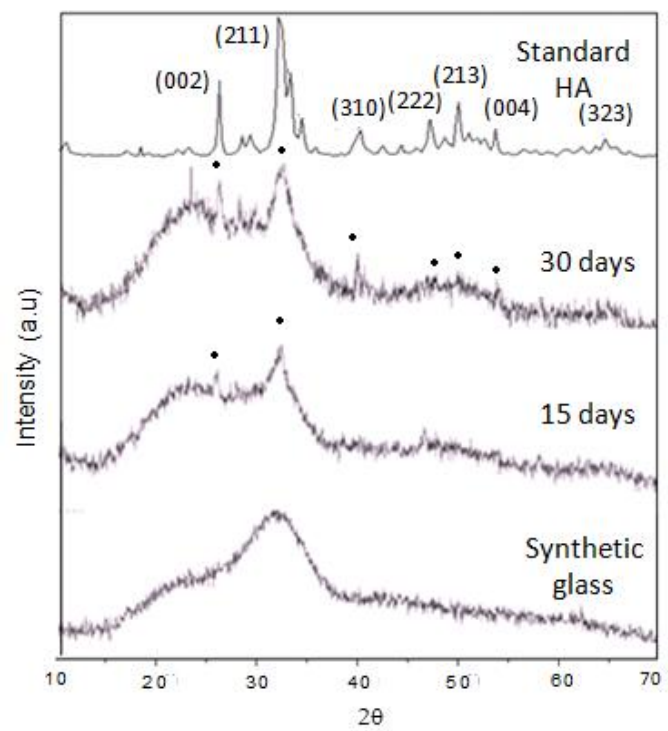

Figure 2. XRD diagrams of Bioglass 45S-Ag before and after "In vitro" experiment.

Table 2. EDX analysis of bioglass 45S-Ag initial

\begin{tabular}{lll}
\hline Element & $\%$ mass & $\%$ atom \\
\hline $\mathrm{O}$ & 42.79 & 57.94 \\
$\mathrm{Na}$ & 14.81 & 13.95 \\
$\mathrm{Si}$ & 21.26 & 16.39 \\
$\mathrm{P}$ & 2.21 & 1.55 \\
$\mathrm{Ca}$ & 18.75 & 10.13 \\
$\mathrm{Ag}$ & 0.18 & 0.04 \\
\hline Total & $100 \%$ & $100 \%$ \\
\hline
\end{tabular}

Table 3. EDX analysis of bioglass 45S-Ag after 30 days of immersion

\begin{tabular}{lll}
\hline Element & $\%$ mass & $\%$ atom \\
\hline $\mathrm{O}$ & 50.07 & 65.88 \\
$\mathrm{Na}$ & 3.60 & 3.30 \\
$\mathrm{Si}$ & 25.19 & 18.88 \\
$\mathrm{P}$ & 5.35 & 3.64 \\
$\mathrm{Ca}$ & 15.83 & 8.31 \\
$\mathrm{Ag}$ & -0.03 & -0.01 \\
\hline Total & $100 \%$ & $100 \%$ \\
\hline
\end{tabular}




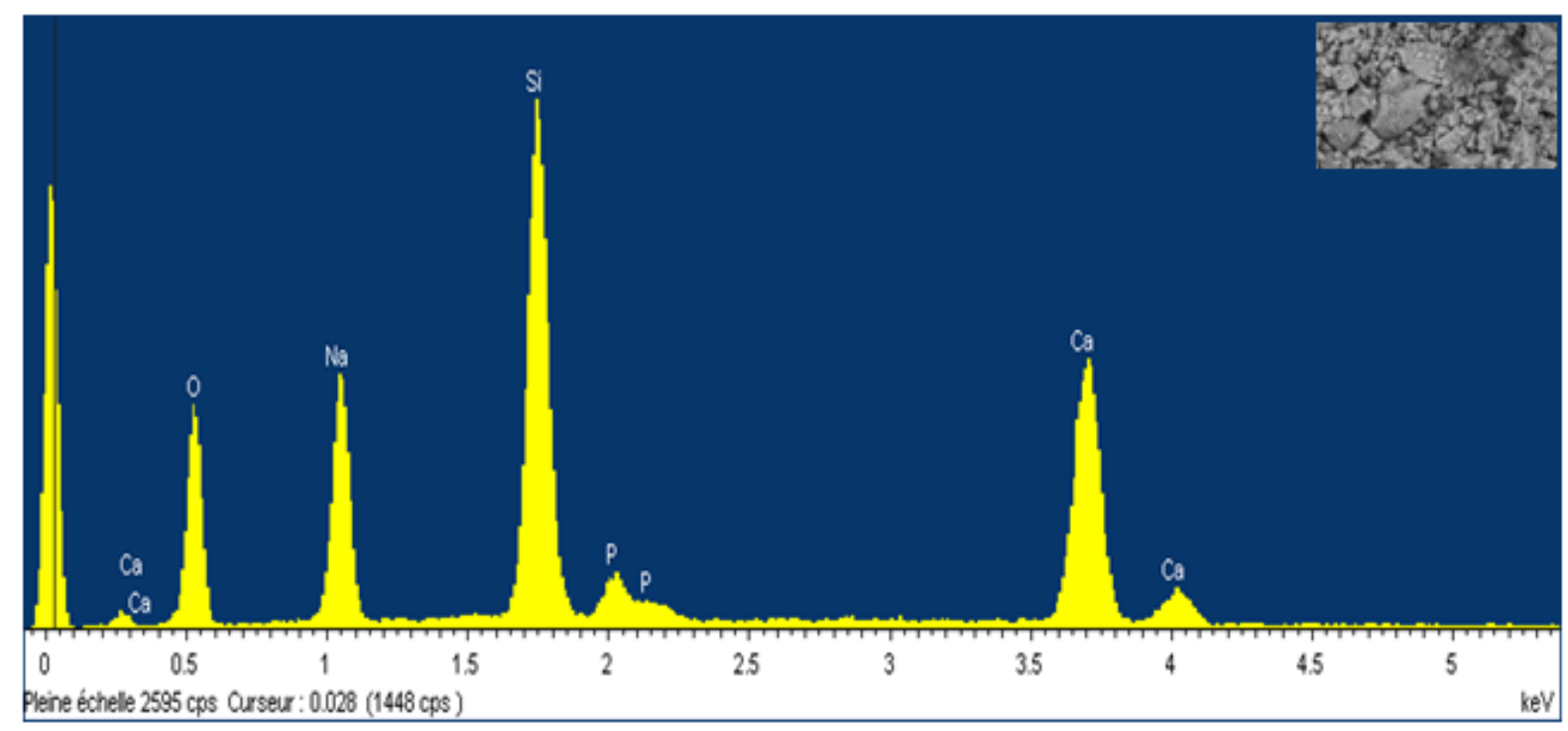

Figure 3. EDX spectrum of 45S-Ag initial.

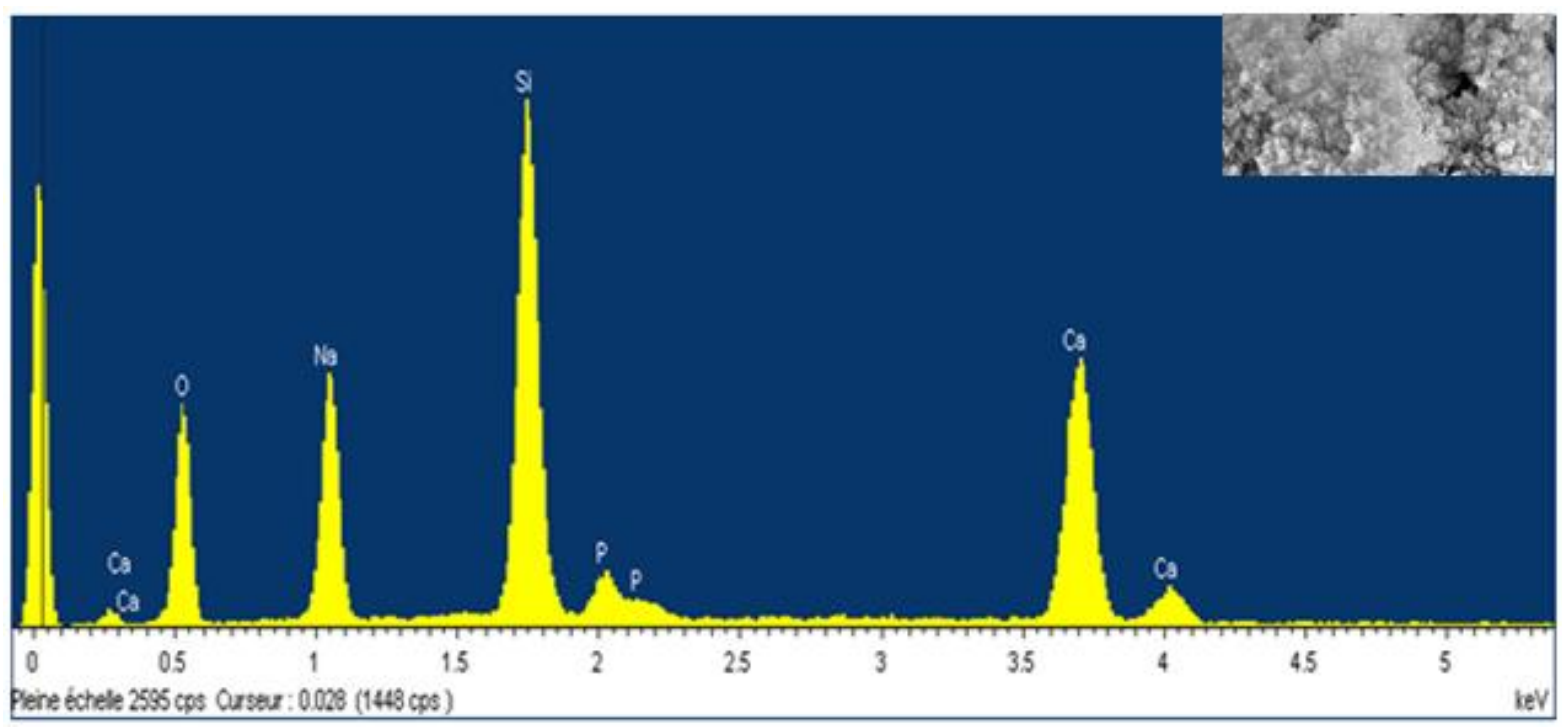

Figure 4. EDX spectrum of 45S-Ag after 30 days of soaking.

\section{SEM analysis}

SEM images of bioglass 45S-Ag are presented in Fig. 5. The surface of initial glass was quite smoothly. After immersion of bioglass in SBF solution, SEM observation showed the important change of surface morphologies when glass samples were dipped in SBF solution. The small particles were appeared on the surface of bioglass 45S-Ag. According to the XRD analysis, this change attributed to the formation of a new apatite layer on the glassy surface. 

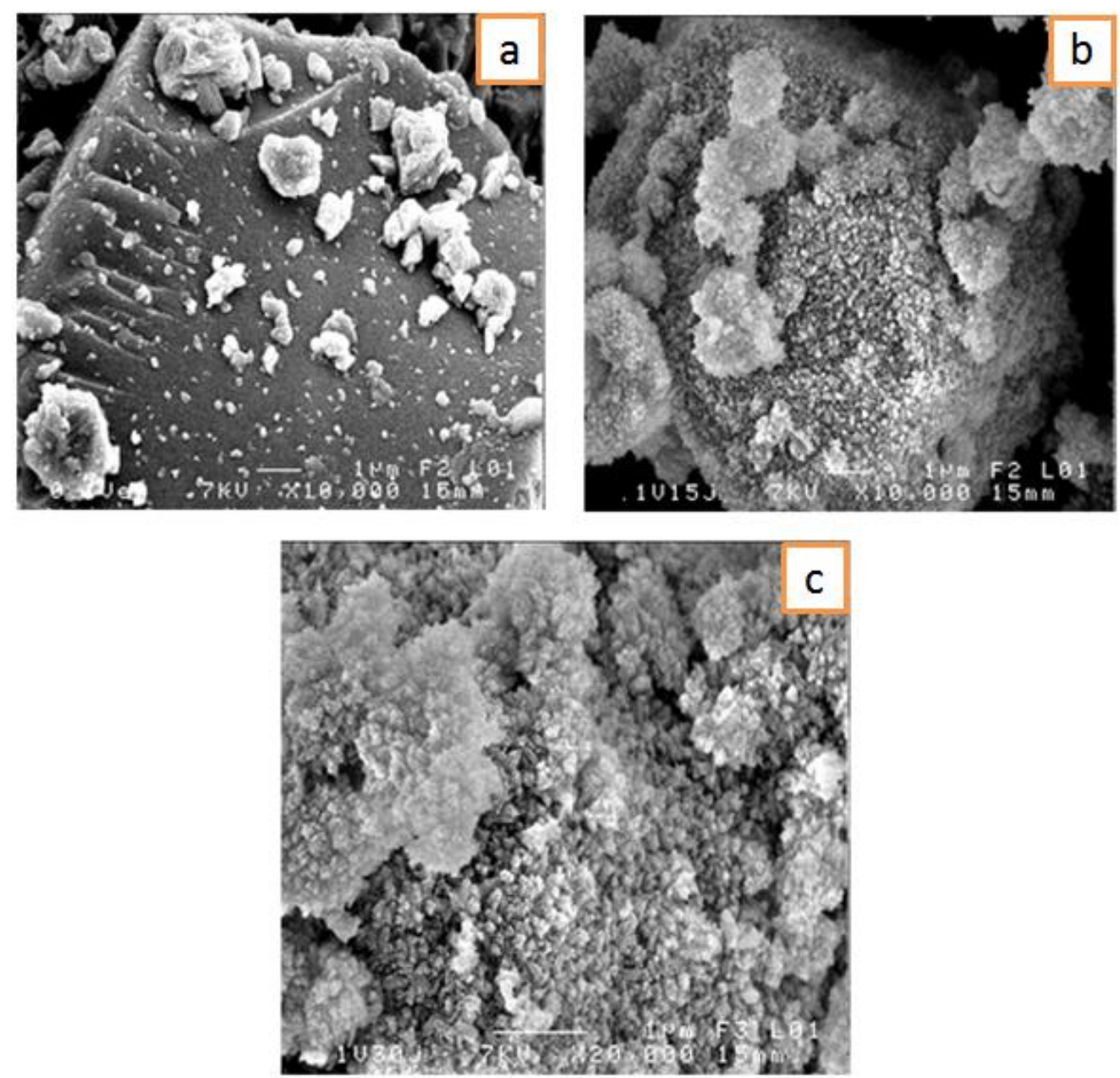

Figure 5. SEM images of glass 45S-Ag before and after immersion: a) glass initial, b) glass after 15 days and c) glass after 30 days of immersion.

\section{Conclusions}

Bioglass 45S doped with Ag was successful synthesized by melting method. DTA showed the effect of $\mathrm{Ag}$ on the character temperatures of bioglass. XRD confirmed the amorphous structure of synthetic glass. EDX analysis strongly illustrated the presence of silver in original bioglass $45 \mathrm{~S}$ matrix and indicated that silver was released when immersing derivative bioglass in SBF solution. XRD and SEM confirmed the bioactivity of bioglass $45 \mathrm{~S}-\mathrm{Ag}$ by formation of a new apatite layer on the surface of bioglass after "In vitro" experiment. So, derivative bioglass still keeps its initial bioactivity characteristics and is a potential biomaterial.

\section{References}

[1] E. Dietrich, H. Oudadesse, A. Lucas-Girot, M. Mami, J. Biomed. Mater. Res., 88A (2008) 1087-196.

[2] L. L. Hench L.L, Journal of Materials Science: Materials in Medicine 17 (2006) 967-978.

[3] I. Ahmed, D. Ready, M. Wilson, and J. C. Knowles, J. Biomed. Mater. Res 79 (2006) 618626. 
[4] D. Kozon, K. Zheng, E. Boccardi, Y. Liu, L. Liverani, A. R. Boccaccini, MDPI-Material, 9 (2016): 225-304.

[5] M. Vallet Regi, Journal of the chemical Society, Dalton Transactions, 44 (2011) 5211-5220.
[6] T. Kokuboand H. Takadama, Biomaterials, 24 (2006) 2907-2915.

[7] Fiche JCPDF 09-432.

[8] E. Dietrich, H. Oudadesse, A. Lucas-Girot A and M. Mami, Journal of Biomedical Materials Research, 88A (2008) 1087-1096.

\section{Tổng hợp và đánh giá vật liệu thủy tinh y sinh 45S-Ag}

\section{Bùi Xuân Vương}

Đại học Sài gòn, 273 An Dương Vương, Phuoòng 3, Quận 5, Tp. HCM

Tóm tắt: Thủy tinh 45S-Ag được tổng hợp thành công bằng phương pháp nấu nóng chảy. Ảnh hưởng của hàm lượng $\mathrm{Ag}$ thêm vào thành phần thủy tinh được đánh giá bằng phương pháp phân tích nhiệt vi sai DTA. Giản đồ nhiễu xạ tia $X$ khẳng định cấu trúc vô định hình của thủy tinh tổng hợp. Thành phần của $\mathrm{Ag}$ trong thủy tinh cũng như sự giải phóng của nó khi tiến hành thực nghiệm "In vitro"' được kiểm tra bằng phổ tán sắc năng lượng tia X. Các kết quả đo nhiễu xạ tia $X(X R D)$ và quan sát bằng kính hiển vi điện tử quét (SEM) khẳng định hoạt tính sinh học của vật liệu $45 \mathrm{~S}-\mathrm{Ag}$ qua sự hình thành lớp khoáng hydroxyapatite (HA) trên bề mặt vật liệu sau thực nghiệm “'In vitro" ngâm bột thủy tinh trong dung dịch giả dịch thể người.

Tù khóa: Thủy tinh y sinh, hoạt tính sinh học, Ag, 45S-Ag, nóng chảy, SBF. 